\title{
Testing for anthropogenic influence on fire regime for a 600-year period in the Jaksha area, Komi Republic, East European Russia
}

\author{
Igor Drobyshev, Mats Niklasson, Per Angelstam, and Przemyslaw Majewski
}

\begin{abstract}
In an attempt to quantitatively evaluate the natural versus anthropogenic signal in site fire histories, the statistical relationship between dendrochronologically dated fire events and tree-ring chronologies (deemed to be an independent proxy for climate variation) was analyzed for 14 sites in a $2600-\mathrm{km}^{2}$ area of pine-dominated forests in the Komi Republic (East European Russia) over the period from 1424 to 1954 . We developed a cumulative measure of statistical fit between two types of fire events (early- and late-season fires) and ring-width chronologies of Scots pine (Pinus sylvestris L.) (total ring- and latewood-width chronologies). For a given site, the statistical fit between fires and tree-ring data tended to decrease with an increasing proportion of unique fire years. Distance from a site to the nearest village (deemed to be a proxy of human impact) explained $50 \%$ of the variation in statistical fit between fires and tree-ring data. The fit decreased in the majority of the sites from the earlier (1424-1700) to the later (1700-1960) periods. We interpret this to be a result of increased human impact on the fire regime since 1700 due to intensified colonization of the area.
\end{abstract}

\begin{abstract}
Résumé : Dans le cadre d'une tentative pour quantifier la part du signal qui est d'origine naturelle et celle qui est d'origine anthropique dans l'historique des feux pour un site donné, nous avons analysé la relation statistique qui existe entre les feux dont la date a été déterminée au moyen de la dendrochronologie et les séries dendrochronologiques (considérées comme un indice indépendant des variations du climat). L'analyse a porté sur 14 sites situés dans une région de $2600 \mathrm{~km}^{2}$ occupée par des forêts dominées par le pin dans la république de Komi (Russie de l'Europe de l'est) pendant la période allant de 1424 à 1954 . Nous avons développé une mesure cumulative du degré d'ajustement statistique entre deux types de feux (en début et en fin de saison) et les séries dendrochronologiques du pin sylvestre (Pinus sylvestris, chronologies de la largeur totale des cernes et de la largeur du bois final). Pour un site donné, le degré d'ajustement statistique entre les feux et les données dendrochronologiques a tendance à diminuer avec l'augmentation de la proportion des années durant lesquelles est survenu un seul feu. La distance entre un site et le village le plus près (considérée comme un indice de l'activité humaine) explique $50 \%$ de la variation dans l'ajustement statistique entre les feux et les données dendrochronologiques. Le degré d'ajustement diminue dans la majorité des sites en passant de la période initiale (1424-1700) à la période finale (1700-1960), ce que nous interprétons comme étant le résultat de l'augmentation de l'impact de l'activité humaine sur le régime des feux depuis 1700 due à l'intensification de la colonisation dans la région.
\end{abstract}

[Traduit par la Rédaction]

\section{Introduction}

Separating the natural, climate-related signals from the human activity related signals in fire chronologies presents one of the major problems in the interpretation of site disturbance histories. In the boreal zone, fire was common both as the main factor driving forest dynamics and as an agricultural tool used to clear the land and grow food for people and their domesticated animals (e.g., Lehtonen et al. 1996; Pyne 1996). As a result, fire chronologies contain a mix of information that reflects both climate variation and differing land-use regimes, complicating their interpretation (Niklasson and Granström 2000; Heyerdahl et al. 2001).

The interplay between climate, humans, and fire regime in the forest is complex (Fig. 1). The link between weather conditions and a fire event in the forest (link 1) is affected

Received 17 November 2003. Accepted 20 April 2004. Published on the NRC Research Press Web site at http://cjfr.nrc.ca on 13 October 2004.

I. Drobyshev. ${ }^{1}$ SUFOR Project, Department of Plant Ecology and Systematics, Ecology Building, Sölvegatan 37, Lund University, S-223 62 Lund, Sweden.

M. Niklasson. SUFOR Project, Southern Swedish Forest Research Centre, Swedish University of Agricultural Sciences (SLU), P.O. Box 49, 23053 Alnarp, Sweden.

P. Angelstam. Grimsö Wildlife Research Station, Department of Conservation Biology, Forest Faculty, SLU, SE-730 91

Riddarhyttan, Sweden.

P. Majewski. Komi Regional Non-Profit Foundation "Silver Taiga" P.O. Box 810, Syktyvkar, 167000 Russia.

${ }^{1}$ Corresponding author (e-mail: Igor.Drobyshev@ekol.lu.se). 
Fig. 1. Interplay between weather settings, humans, and fire events in the forest. Plus signs and minus signs depict, respectively, positive and negative feedbacks in the system.

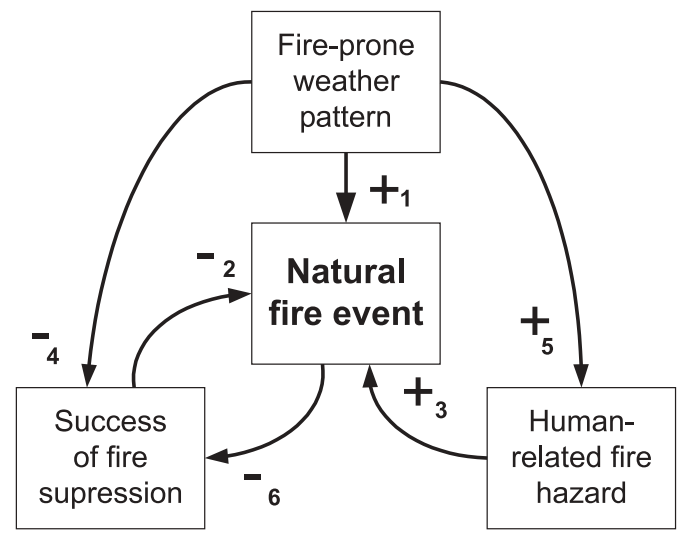

by fire suppression (link 2) and the "agricultural" use of fire (link 3). Fire-prone weather would likely limit the impact of fire suppression (link 4) and increase the human-related fire hazard (link 5). Occurrence of fire generally reduces the impact of fire suppression (link 6). In this paper, we focus on the link between fires and high-frequency (annual) weather variation as reconstructed from tree-ring data and do not discuss other controls of fire activity (e.g., fuel build-up and time since fire).

In our analysis, we limit the definition of natural fire regime to the temporal and spatial variation in the occurrence and properties of fire events that are controlled primarily by climate variation (link 1, Fig. 1). Human-related fire regime is, in turn, a variation in fire activity primarily due to human activities (links 2 and 3, Fig. 1). Consequently, a statistical fit between independently reconstructed fire-prone weather data and a fire event under natural conditions (in an area devoid of humans) represents the "natural signal" in fire chronology. The stronger the statistical correlation between these two phenomena, the stronger the natural signal is assumed to be in the fire chronology. In this paper, we attempt to evaluate the role of link 1 against the overall impact of links 2 and 3.

There are several intrinsic difficulties in using tree-ring data to separate the natural signal from the anthropogenic one in fire chronologies. One arises from the fact that tree-ring chronologies record environmental variation at monthly and seasonal time scales (Fritts 1976), while conditions promoting fire initiation and spread normally develop within days or weeks (Johnson 1992). This naturally decreases the sensitivity of tree-ring data for recording such a signal. Another difficulty is that fire-prone weather does not necessarily lead to ignition and the subsequent spread of fire in the particular area that is being sampled for fire history. Put simply, both the temporal and spatial scales of fire-prone weather and ignitions are rarely covered in local fire histories as recorded in tree-rings. Thus, information on the occurrence of a fire during a season with likely fire-prone weather provides limited opportunity to judge the "naturalness" of a particular fire event. However, considering the length of typically available fire chronologies (several centuries) and lack of other data with similar temporal resolution, even this information is of value.
In this paper, we attempt to provide a tool to improve the separation of climate- and human-related signal in fire chronologies. We do this by coupling seasonally resolved fire chronologies with independently collected tree-ring chronologies from an area in the Komi Republic in East European Russia. We attempted to rank each site studied by the strength of climatic versus nonclimatic signals in its fire chronology. Using this method, we tested three hypotheses regarding the site-specific features of fire regime:

(i) The proportion of dendrochronologically dated fires with large inferred spatial extent should be greater in sites with a stronger climate-fire link.

(ii) Sites located farther away from a village should exhibit a stronger climate-fire link.

(iii) Over time, the statistical strength of the climate-fire interaction should generally decrease as a result of increasing human population in this part of the Komi Republic.

The first hypothesis assumes that the larger fires are most likely a result of weather (natural) conditions, as represented by link 1 in Fig. 1. The second hypothesis uses distance to the nearest village as a substitute for the human influence on a given site. The second and third hypotheses endeavour to combine effects represented by links 2 and 3 (Fig. 1).

\section{Materials and methods}

\section{The method}

The method used focuses on classification of single sites with respect to the dendrochronological proxy of the climate during a particular fire season. This approach is based on the findings of Drobyshev et al. (2004), which show a link between ring width in Scots pine (Pinus sylvestris L.) and fire occurrence during a particular part of the growing season in an area in the central part of the Komi Republic (Fig. 2). Years with fires at the beginning of the growing season ("early-season fires") tended to have negative departures in total ring-width chronology, and years with fires dated to the end of the growing season ("late-season fires") showed positive departures in the latewood-width chronology. The former was most likely caused by the negative influence of high aridity on cell elongation at the beginning of the growing season, and the latter was most likely the result of the positive correlation between lignin accumulation, cell elongation, and temperature during the second half of the growing season (Kalela-Brundin 1999). Drobyshev et al. (2004) found that the connection between the occurrence of late-season fire and wider latewood rings was statistically stronger than that between the occurrence of early-season fire and narrower total ring width. However, here we treat these two effects as being equally significant and make no adjustment for the variation in their statistical expression. We also make the following assumptions:

(i) In a continental climate, there is a direct, positive correlation between growing-season temperature and aridity (Kutzbach and Webb 1993), and this is also positively correlated with the probability of forest fires occurring and spreading.

(ii) The size of the departures from the tree-ring indices for the years with dated fires are indicative of the strength of climate signal in a particular site's fire chronology. 
Fig. 2. Study area and complete fire histories for each site. Dates represent years of recorded fires.

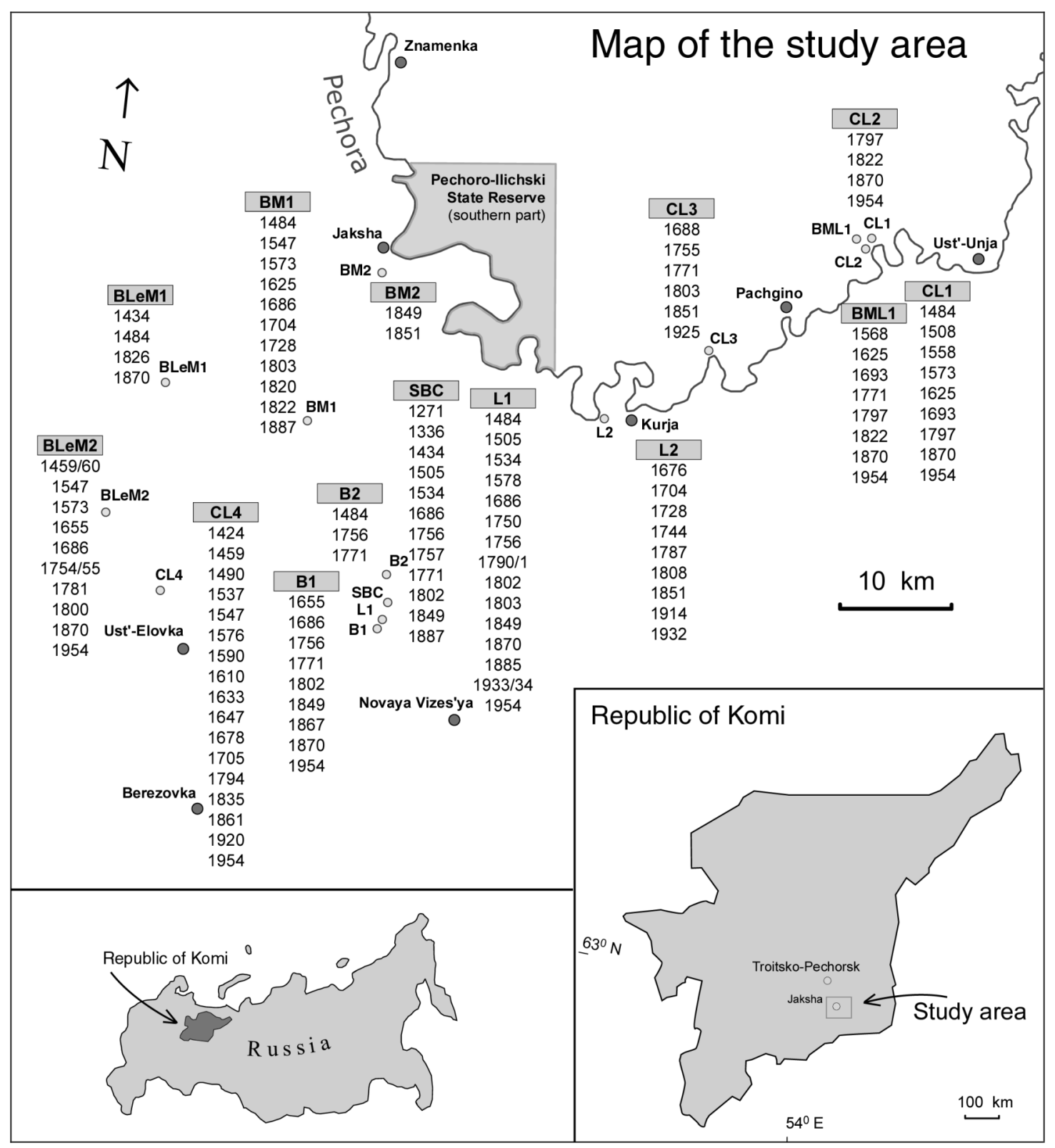

In this study, ring-width departures were used to calculate the "climatic departure index", which is the sum of two site-specific averages: the average of the total ring-width departures in years with early-season fires plus the average of latewood-width departures in the years with late-season fires. Because we did not have years with fires at both the beginning and the end of the season in our data set, we consider these two types of width departures as two independent proxies for the climatic signal in the site fire chronologies. In other words, two independent sets of years were used to produce two types of departures. For each site, the absolute values of two averages were summed up to reduce several variables to one climatic departure index.

To verify the site ranking produced on the basis of the climatic departure index, two features of the studied sites were considered. One was the percentage of the dated fires ob- served at a particular site that occurred when a fire was recorded at any other site in the same year. A study of the multicentury fire regime of the Swedish boreal landscape (Niklasson and Granström 2000) showed that, during human colonization of the area, the fire pattern changed from a few large fires to many smaller fires. Thus, a site with a high proportion of fire years when fires were also recorded at other sites was probably experiencing little influence from human activities. On the contrary, a site with a high proportion of fire years unique to it was probably influenced to a higher degree by human activities. Similar reasoning for separating the natural from the human-mediated factors behind disturbance events has been used in other fire-history studies (Lehtonen et al. 1996).

The second site feature considered in this study was the distance from a site to the nearest village. This parameter 
Table 1. Description and classification of sites used in the study.

\begin{tabular}{llclc}
\hline Site No. & Site type and stand composition ${ }^{a}$ & No. of samples taken & Site code & Site type $^{b}$ \\
\hline 1 & Lichen, 10 PSyl & 12 & L1 & Cowberry-lichen \\
2 & Blueberry, 9 PSyl : 1 PO & 3 & B1 & Blueberry \\
3 & Cowberry-lichen, 10 PSyl & 17 & CL1 & Cowberry-lichen \\
4 & Cowberry-lichen, 10 PSyl & 5 & CL2 & Cowberry-lichen \\
5 & Blueberry - green moss - lichen, 10 PSyl & 8 & BML1 & Blueberry \\
6 & Cowberry-lichen, 10 PSyl & 5 & CL3 & Cowberry-lichen \\
7 & Lichen, 10 PSyl & 5 & L2 & Cowberry-lichen \\
8 & Blueberry - green moss, 8 PSyl : 1 LS : 1 BP & 11 & BM1 & Blueberry-moss \\
9 & Blueberry, 10 PSyl & 11 & B2 & Blueberry \\
10 & Blueberry - Ledum - green moss, 10 PSyl & 12 & BLeM1 & Blueberry-moss \\
11 & Blueberry - Ledum - green moss, 6 PSyl : 3 PO : 1 PSib & 19 & BLeM2 & Blueberry-moss \\
12 & Cowberry-lichen with green moss and Ledum, 10 PSyl & 15 & CL4 & Cowberry-lichen \\
13 & Blueberry - green moss, 10 PSyl & 3 & BM2 & Blueberry-moss \\
14 & Sphagnum - blueberry - cowberry, 10 PSyl & 15 & SBC & Blueberry-moss \\
\hline
\end{tabular}

${ }^{a}$ Tree species: PSyl, Pinus sylvestris; PO, Picea obovata; BP, Betula pubescens; LS, Larix sibirica; PSib, Pinus sibirica. Numbers refer to the visually estimated proportion (on a base of 10) of basal area accounted for by each tree species within a site.

${ }^{b}$ The three site types, defined on the basis of ground-floor vegetation, were used in an ANCOVA analysis.

was assumed to be a quantitative portrayal of human impact on the site disturbance regime over the period studied. To measure this, we used historical data on local settlements.

\section{Study area}

The study area was located in the southeastern part of the Komi Republic, the most forest-rich region in the northeastern part of European Russia (Fig. 2). The republic has an area of $415900 \mathrm{~km}^{2}$ and is located within two major land shields, the Russian Shield in the southwestern part of the republic and the Pechora Shield in the northeastern part (Dedeev 1997). The most common soil types there are moraine and surfaced loams (Zaboeva 1997). The forested area totals about $300000 \mathrm{~km}^{2}$, which constitutes $4.1 \%$ of the total Russian forested areas (Komi ASSR administrative map 1981). Climatically, the republic lies within Arctic, Atlantic-Arctic, and Atlantic-continental provinces (Republic of Komi 1997). The annual average temperature ranges from $1{ }^{\circ} \mathrm{C}$ in the southern part of the republic to $-6{ }^{\circ} \mathrm{C}$ in the northern part, and the average length of the growing season (days with average daily temperature above $10^{\circ} \mathrm{C}$ ) ranges from 110 to 45 days, respectively. Annual precipitation averages $700 \mathrm{~mm}$ in the south and $450 \mathrm{~mm}$ in the north. Accumulation of thick snow cover $(70-80 \mathrm{~cm})$ is characteristic for the winter period, which lasts for 130-200 days.

The prevailing vegetation cover in the Komi Republic is middle and northern taiga forest, with the exception of the mountainous part of the Republic, where forest-tundra and tundra ecosystems develop (Larin 1999). Boreal vegetation is dominated by two pine species (mostly Pinus sylvestris and, less commonly, Pinus sibirica Du Tour), Siberian spruce (Picea obovata Ledeb.), and Siberian fir (Abies sibirica Ledeb.). Birch (Betula pubescens Ehrh.) forests are typically the early stages of postfire succession and often contain abundant Populus tremula L.

Field sampling was done in the southeastern part of the republic, close to and within the southern part of the Pechoro-Ilychsky Biosphere Reserve (Anufriev 2000). The administrative centre here is Jaksha village $\left(61^{\circ} 05^{\prime} \mathrm{N}\right.$; $57^{\circ} 00^{\prime} \mathrm{E}$ ), located in the valley of the Pechora River (Fig. 2).
In this area, average daily temperature begins to exceed $10{ }^{\circ} \mathrm{C}$ during the first 10 -day period of June and then falls below this value again in the first week of September. Complete snow melt in the pine forests occurs in mid-May and the first snow cover usually occurs in the first week of October.

\section{Field sampling}

In 1994, complete cross-sections of logs and stumps of Scots pine (Pinus sylvestris L.) were taken from dead and live trees and stumps within a $70 \mathrm{~km} \times 37 \mathrm{~km}$ area centred approximately on Jaksha village (Fig. 2). In total, 14 sites were sampled for fire scar evidence (Table 1). The shortest and the longest distances between any two sites ranged from 0.2 to $73.0 \mathrm{~km}$ (Fig. 2). The sites and villages in the area were mapped, and the distance between each site and the nearest settlement was recorded.

Each site was approximately 0.5 ha. During sampling, an attempt was made to search throughout the whole of each site to collect samples of living trees (not common) and dead trunks or stumps (much more common) bearing fire scars. Cowberry-lichen, blueberry, and blueberry-moss site types were also sampled (Table 1). Site CL4 was clearcut in the summer of 1993, and sites BM1 and BLeM1 showed signs of selective cuttings.

\section{Chronology building}

Cores of pine trees were taken at breast height from several sites around Jaksha village (Fig. 2), and complete pine disks from the same study sites were used to construct the total ring-width and the latewood-width chronologies. Although some of the samples originally collected for fire scar dating were used to develop the chronologies, a careful sample selection was made to avoid ring sequences showing a likely nonclimatic growth pattern. This was done by excluding both those samples that had scars occurring within the sequence of rings to be measured and those samples showing periods of growth releases and depressions after years with dated fires on the same site. 
Both earlywood and latewood width were measured using the Aniol measuring stage controlled by CATRAS software (Aniol 1983). Boundaries between earlywood and latewood were determined according to differences of colour, cell size, and relative cell wall thickness (Kalela-Brundin 1999). Single-tree chronologies were cross-dated and verified by use of the signature years (Stokes and Smiley 1968) and by application of two computer programs: CATRAS (Aniol 1983) and COFECHA. The latter program is a part of the International Tree-Ring Data Bank Program Library (version 2.1) (Grissino-Mayer et al. 1997).

\section{Data analysis}

To remove the nonclimatic trends in width increments, single series were double detrended through the use of negative exponential or linear functions within the ARSTAN program (Grissino-Mayer et al. 1997). Because the focus of this study was on the seasonally resolved link between the tree-ring and fire data sets, the width chronologies used were residual chronologies that preserve primarily high-frequency (annual) variation in the record. We used total ring-width and latewood-width chronologies covering the period of about 1400 to1960. To assess the strength of the common signal in chronologies, the expressed population signal (EPS) (Wigley et al. 1984), which is the correlation between the actual sample chronology and the theoretical population chronolog based on an unlimited number of samples, was assessed for all residual chronologies. An EPS value of 0.80 was attained (with the sample of six trees) by total-width chronology since 1410 and by latewood-width chronology since 1393 . For the analyzed time frame (1400-1960), the EPS values for these chronologies were 0.84 and 0.85 , respectively, which is very close to the critical limit of 0.85 proposed by Wigley et al. (1984).

Because early- and late-season fires showed different relationships to the tree-ring record, only fires with clear seasonal dating were selected for the analysis. Additionally, fires dated to the middle of the growing season were excluded. In such cases, the fire scars were located on the border between latewood and earlywood portions of a tree ring. However, all fire dates (with and without seasonal dating) were employed for the analysis of the fires' spatial extent.

To check for effect of site type on climate-fire interaction, an analysis of covariance (ANCOVA) was performed, using the three site-type codes as the independent factor (Table 1), climatic departure index as the dependent variable, and distance to the nearest village as the covariate. The three site types were cowberry-lichen, blueberry, and blueberry-moss (factor levels 1, 2, and 3, respectively).

Linear regressions were employed to establish the relationship between climatic departure index and site attributes. To assess the statistical robustness of the linear regression coefficients, the bootstrap method (Efron and Tibshirani 1994) was applied to produce empirical 2.5 and 97.5 percentiles of the coefficient distributions. This was done by randomly resampling half of the original number of sites $(n=14 / 2=$ 7) and generating $1000 r$ coefficients to build up their empirical distributions in each analysis.

To check for the presence of a temporal pattern in the association between fire events and tree-ring data, the whole data set was split into two periods: 1424-1700 and
1700-1960. The reason for establishing 1700 as a boundary is that historical evidence indicates that most of the settlements in the area were established during the 1700s to early 1800s (Zherebtsov 1971, 1972; Republic of Komi 1997-2000).

\section{Results}

Sites showed considerable variation in the size of the tree-ring departures during years that had dated fires. The general pattern observed was negative departures of total ring width for years with early-season fires and positive departures of latewood width for years with late-season fires (Fig. 3). Site BM1 had the highest departures of both total ring width and latewood width, and site CL3 appeared to deviate from the general pattern found for both early- and late-season fires. In 1771, fires were recorded at several sites, coinciding with negative latewood-width departure.

We checked whether these two patterns of association between fire events and width chronologies were related to each other. We assumed that $(i)$ both patterns were the result of climate-controlled (natural) fire activity in the studied area and (ii) if a site had experienced the "natural" fire activity, both early- and late-season fires should confirm it. In other words, we assumed that width departures in the fire years with early-season fires would correlate with width departures in the years with late-season fires. Since the characteristic departures were of different signs (negative for early-season fires and positive for late-season fires), we expected the correlation to be negative.

Departures of total ring width were negatively correlated with latewood-width departures over all sites (Fig. 4). Therefore, the absolute values of width departures during fire years were positively correlated among sites. This implies that a site showing a stronger statistical relation between tree-ring data and fire events in one part of the fire season also showed a stronger relation in another part of that season, as compared with other sites. Based on this reasoning, absolute values of width departures were summed up to obtain the climatic departure index for each site.

The index tended to be positively correlated to the proportion of fire years recorded at a specific site and at least one other site, with the amount of variance accounted for in a linear regression being $29.1 \%(p=0.071)$ (Fig. 5). Distance from a site to the nearest village showed a strong positive correlation with the climatic departure index during a fire year and accounted for $50.1 \%$ of the variance in a linear regression ( $p=0.005$ ) (Fig. 6). Bootstrapping the regression coefficient and $R^{2}$, with the group size being half the total number of sites $(n=7)$, produced a mean $r=0.030$ and $R^{2}=$ 0.496. ANCOVA demonstrated no impact of site type on the strength of association between climatic departure index and dated fire events $(F=0.140, p=0.869)$. Although the climatic departure index had a tendency to increase from dry to more mesic sites $(0.098,0.146$, and 0.234 , respectively, for the cowberry-lichen, blueberry, and blueberry-moss site types), most of the variation was accounted for by the covariate $(7.55,10.73$, and $14.6 \mathrm{~km}$, respectively, for the cowberry-lichen, blueberry, and blueberry-moss site types).

There was a clear tendency for the climatic departure index to decrease over time (Fig. 7). This effect was observed at most of the sites and concerned both early- and 
Fig. 3. Classification of single sites with respect to the climatic departure index during fire years. Year and site departures of total ring width $(a)$ and latewood width $(b)$ for the years with early-season $(a)$ and late-season $(b)$ fires recorded at the studied sites. The larger the absolute value of the average width departure for a site, the stronger climate control is assumed for the fire events occurring at this site. Early-season fires are associated with negative ring-width departures and late-season fires with positive latewood-width departures. However, not all fire years and not all sites conform to this general pattern.

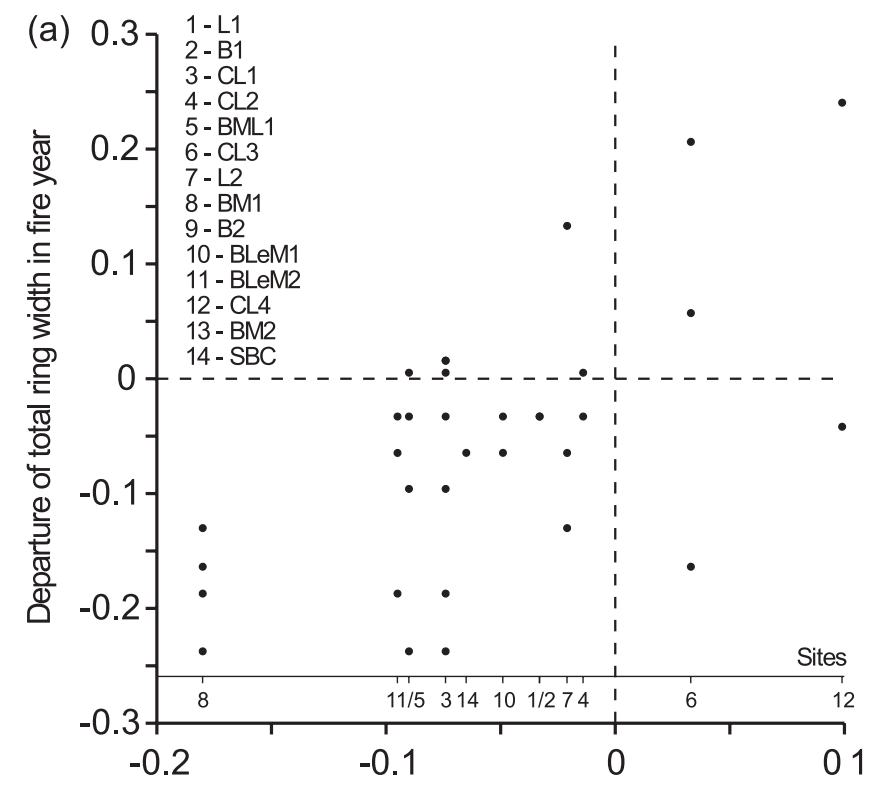

Average ring-width departure in fire years for a site

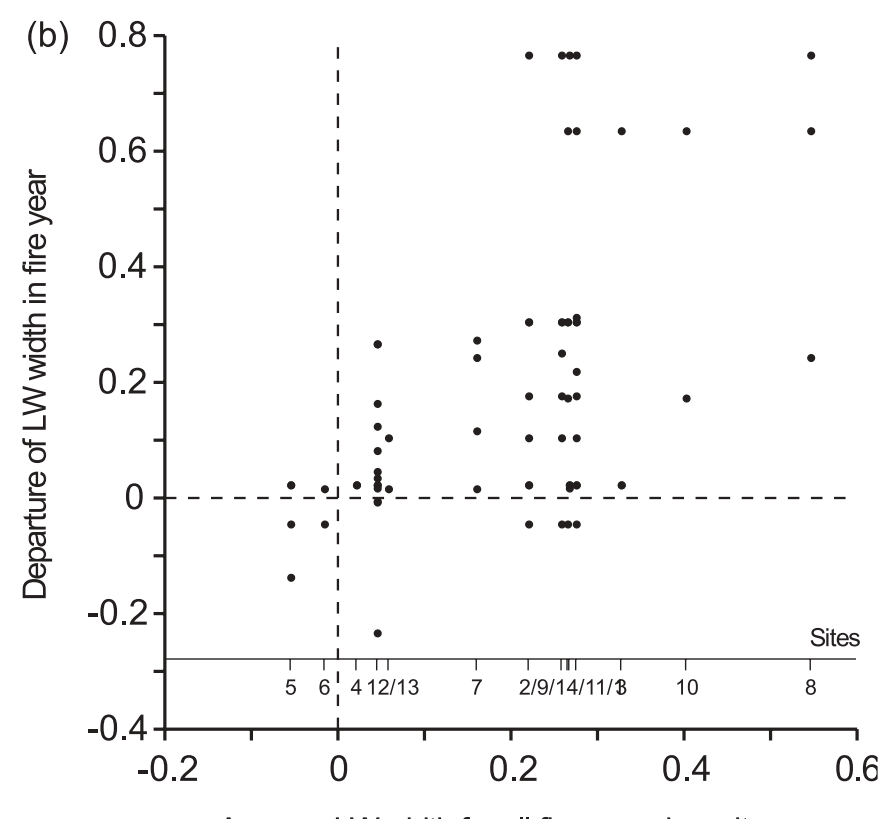

Average LW width for all fire years in a site

late-season fires. Three of the sites with a deviating temporal pattern had both statistically weak (sites CL4 and BML1) and strong (site BLeM1) climate-fire links.
Fig. 4. Total ring-width departures contrasted against latewood-width departures during dated fire years for each site.

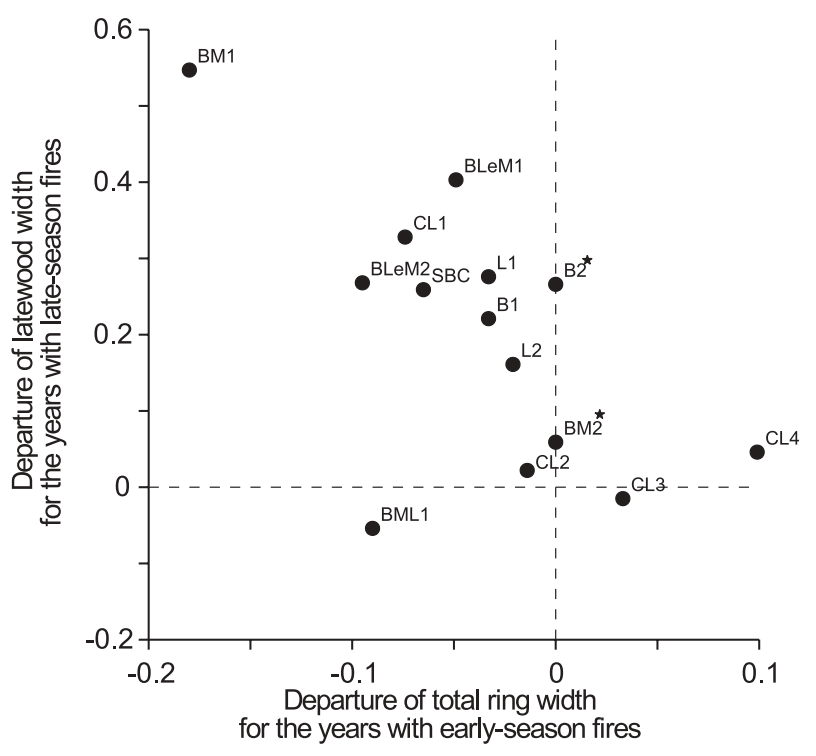

Fig. 5. Linear regression between the fire index (proportions of fire years recorded at more than one site) and the climatic departure index. No difference between early- and late-season fires was made in the calculation of the fire index. Site BM2 was excluded, because it contained only two seasonally dated fire years in its chronology. Dotted lines show the higher and lower $2.5 \%$ limits of the regression coefficient distribution obtained though bootstrapping (number of replications 1000, group size 7).

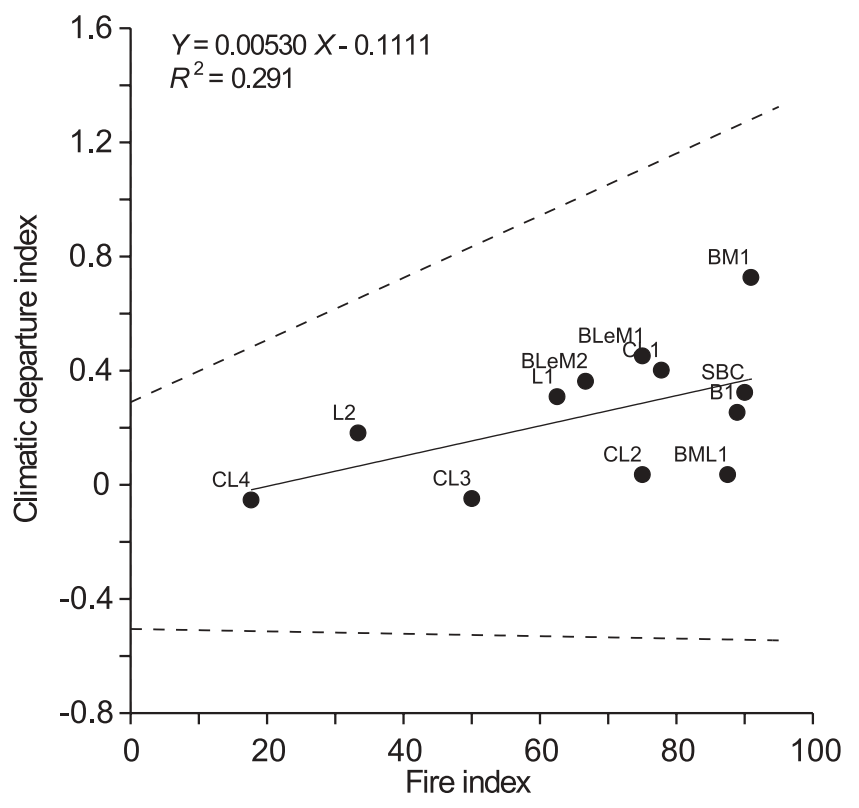

\section{Discussion}

Climatic departure index and site fire histories

Using the tree-ring proxy of past seasonal climates appears to be helpful for judging how the fire regime is controlled by climate. Despite the variation in the strength of 
Fig. 6. Linear regression between distance from a site to the nearest village and the climatic departure index. Dotted lines show upper and lower $2.5 \%$ limits of the regression coefficient distribution obtained though bootstrapping (number of replications 1000, group size 7).

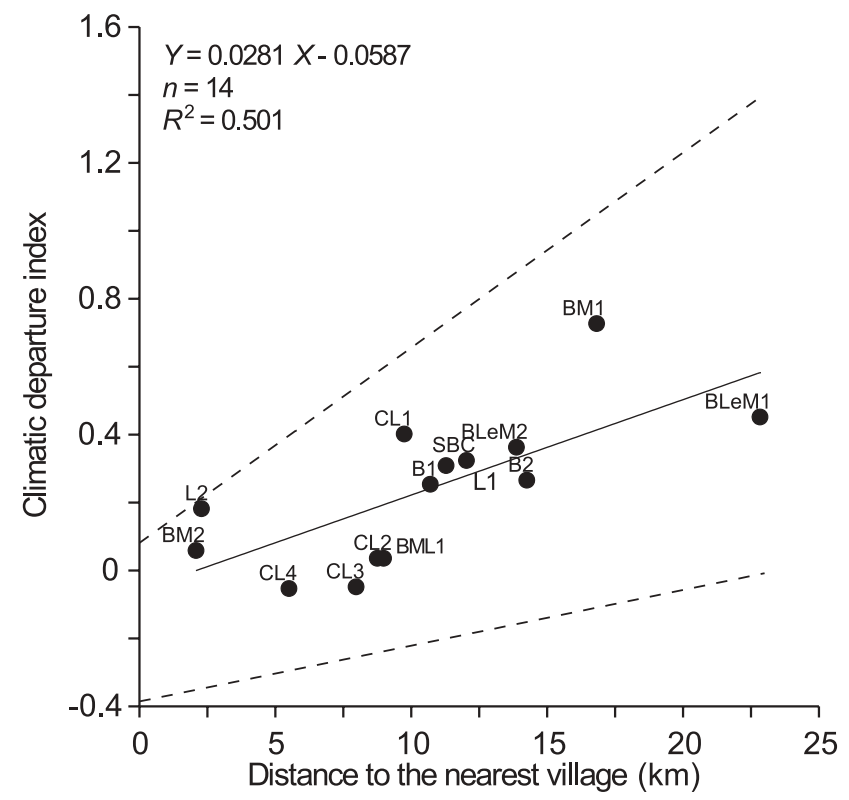

the statistical fit between tree-ring and fire records, early-season fires tend to coincide with negative ring-width departures and late-season fires with positive latewood-width departures. The presence of these two patterns in the data set (Figs. $3 a$ and $3 b$ ) allowed ranking of the sites with respect to the inferred climatic control over their fire regimes (Fig. 4). We assumed that sites showing a differing pattern related to the climate-fire link were likely affected by human activities in the past. A preliminary piece of supporting evidence was that sites deviating with regard to early-season fires also tended to deviate with respect to late-season fires (sites CL2 and CL4, Fig. 4). This could be a result of the fire-mediating human activity in the forest being spread over the entire warm season in this area.

Distance from a site to the nearest village explained $50 \%$ of the variation in the statistical fit between fire events and climatic departure index among sites (Fig. 6). This supports the second hypothesis. Of particular importance is that the sites that defined the variation in the distances (site BM1 vs. sites CL2 and CL4) were at the same time defining the range of variation in the climatic departure index. We propose that this pattern is a result of human activities being concentrated mainly around settlements. These considerations are in line with other studies that point to the strong influence of settlements and timing of human colonization periods (Swetman 1996; Niklasson and Granström 2000), as well as the influence of the shifts in forest-use practices (Lehtonen at al. 1996), on forest fires in the boreal landscape. An interview with a local ranger (P. Lizlov, personal communication) revealed that the daily trips of hunters and gatherers in the taiga usually did not exceed a $10-\mathrm{km}$ radius from a village or hunter's cabin. Even today the shortest distance between two forest cabins or ranger farms is typically $10 \mathrm{~km}$ (I. Drobyshev, per- sonal observation). In this context, the pattern of association between climatic departure index and distance to the nearest village may indicate a spatial threshold of human impact on site fire regime, found to be around $10 \mathrm{~km}$ from the village.

The proportion of fire years recorded at a site and also known from other sites (i.e., the proportion of likely large fire events among all fire events recorded at a site) was positively related to the strength of the statistical link between tree-ring record and fire chronology (Fig. 5). This is consistent with the first hypothesis. We assume that annual synchrony of fire occurrence over the studied area is more a product of climate settings than of human activities (Weber and Stocks 1998; Veblen et al. 2000), partly because of strong climatic control over fuel conditions (Johnson 1992) and lightning ignitions (Granström 1993; Nash and Johnson 1996). If this assumption holds, then the negative correlation between the climatic departure index and the proportion of unique fire years warrants the proposed tree-ring-based assessment of the climatic signal in site fire chronologies. However, bootstrapping showed that the statistical robustness of the association between the climatic departure index and the proportion of common fire years recorded at a site was moderate, with the regression coefficient having negative values within $95 \%$ of its distribution range.

\section{Temporal change in climate-fire link}

For the years with dated fires, the climatic departure index decreased over time in most of the sites (hypothesis 3) (Fig. 7). Such decreasing influence of high-frequency climatic variability on fire regimes has been generally related to the expansion of human activities (e.g., fire suppression) in forests over the last century (Swetnam 1996; Veblen et al. 1999). In our study area, we attribute this to increasing human impact on fire regime as a result of an almost 100-fold increase in population size in the Komi Republic during the last five centuries (Republic of Komi 1997-2000).

According to the first historical records in 1585 , the population of the whole region was about 20000 (around 0.05 individuals $/ \mathrm{km}^{2}$ ) (Zherebtsov 1971). Today it is 1.12 million (Republic of Komi 1997-2000). Although historical data on specific settlements is scarce, the recorded history of most of the villages in this part of the Komi Republic can be traced back to the 17th century (Republic of Komi 1997). From the 1500 s to the 1800 s, villages in the area consisted of one to five families. After that, the region's population began to increase, the result of colonization by Russian people (Zherebtsov 1972). The larger population may have affected site fire regimes through wider and more frequent use of fire for agricultural purposes (primarily through slash-and-burn farming) and maintenance of grazing grounds and a higher frequency of single bonfires (Pyne 1996). Such fires escaping human control and spreading into the natural forested landscape were likely interlinked with climatically controlled (natural) events.

Slash-and-burn, a common practice in the republic in the past, was apparently introduced in the 5th-6th century AD (Smirnov 1952). Transition to "three-field" and "two-field" agricultural systems, characterized by less intensive clearing of the forested land, began in the 15th century (Smirnov 1952; Belitser 1958). Nevertheless, the use of fire for the cultivation of rye, barley, and wheat was frequent up until 
Fig. 7. Change of total ring-width (for the early-season fires) and latewood-width (for the late-season fires) departures for the years with dated fires. Short horizontal lines depict average departures for each site, with the arrow originating at the value for the period 1424-1700 and pointing to the value for the period 1700-1960. Sites shown had at least one early- or late-season fire during these periods.

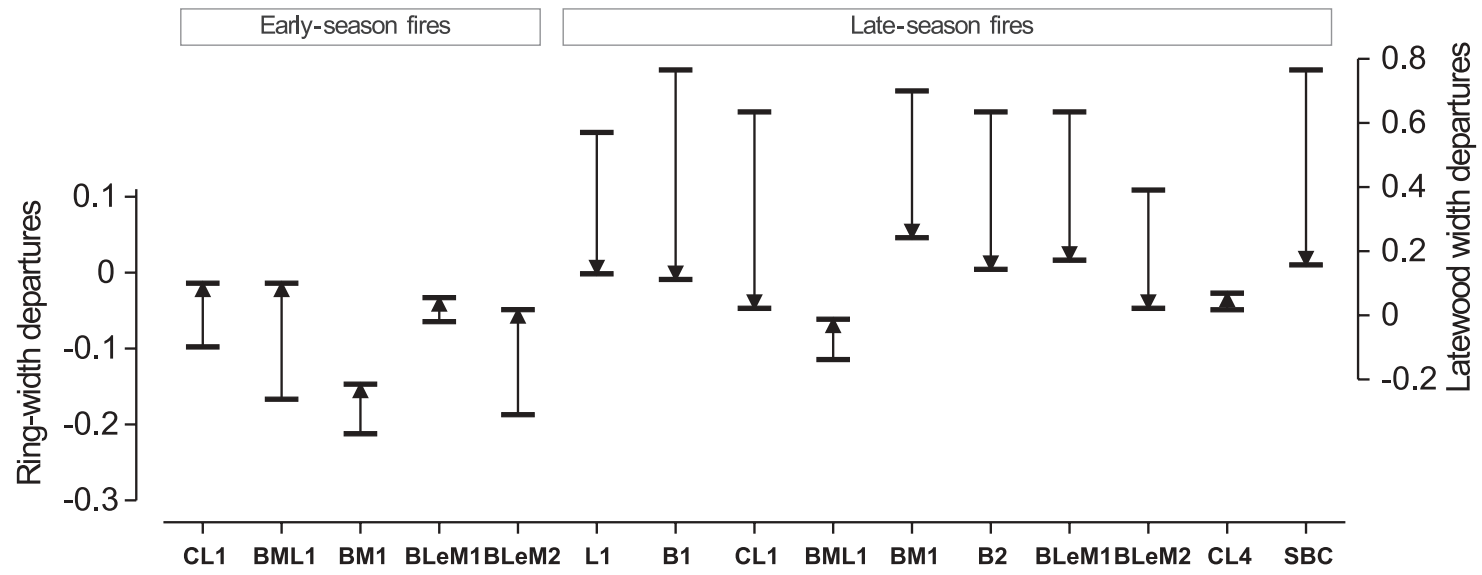

Table 2. Seasonal timing of dated fires in early (before 1700) and late (after 1700) periods in the study area.

\begin{tabular}{|c|c|c|c|c|}
\hline \multirow[b]{2}{*}{ Site } & \multicolumn{2}{|l|}{ Before 1700} & \multicolumn{2}{|l|}{ After 1700} \\
\hline & Early-season fires & Late-season fires & Early-season fires & Late-season fires \\
\hline $\mathrm{L} 1$ & 0 & 3 & 1 & 6 \\
\hline B1 & 0 & 1 & 1 & 5 \\
\hline CL1 & 5 & 1 & 2 & 1 \\
\hline CL2 & 0 & 0 & 2 & 1 \\
\hline BML1 & 2 & 1 & 2 & 2 \\
\hline CL3 & 0 & 0 & 3 & 2 \\
\hline L2 & 0 & 0 & 3 & 4 \\
\hline BM1 & 2 & 2 & 2 & 1 \\
\hline B2 & 0 & 1 & 0 & 3 \\
\hline BLeM1 & 1 & 1 & 1 & 1 \\
\hline BLeM2 & 1 & 2 & 2 & 1 \\
\hline CL4 & 2 & 5 & 0 & 6 \\
\hline BM2 & 0 & 0 & 0 & 2 \\
\hline SBC & 1 & 1 & 0 & 5 \\
\hline Total & 14 & 18 & 19 & 40 \\
\hline
\end{tabular}

Note: Only fires with definite seasonal dating are included.

the beginning of the 20th century (Konakov 2004), even despite the official ban on slash-and-burn farming at the end of the 18th century (Kozubov and Taskaev 1999). During a slash-and-burn, a site (typically around 1 ha) was normally burnt during the spring (Belitser 1958). In our data set, the dominance of late-season fires implies a rather natural pattern of site fire regimes (M. Niklasson, I. Drobyshev, and P. Angelstam, unpublished data). Seasonal timing of dated fires did not reflect the likely increase we expected in the use of slash-and-burn since 1700 when the population of the region started to expand (Republic of Komi 1997). In the hemiboreal zone of Sweden, strong shifts in fire season have been recorded, with early-season fires showing a large seasonal variability and late-season fires being more predominant in the dormant season, possibly as a result of strongly increased human impact (Niklasson and Drakenberg 2001). In our data set, fire season did not reveal any trend between the early (before 1700) and late (after 1700) periods, either for the whole data set or for groups of sites with a similar climatic departure index (Table 2). Therefore, we believe that the strong correlation between climatic departure index for a site and distance to the nearest village points to the important role of the cumulative impact of humans, who both provided sources of ignitions and attempted to control natural fires (Fig. 1, links 2 and 3).

A changing association between climate and natural fire might be another reason for the decreasing influence of highfrequency climatic variability on fire regimes. Available firehistory studies suggest that a decrease in fire frequency observed in boreal regions is not fully attributable to fire suppression and may instead have a climatic explanation (Bergeron and Flannigan 1995; Flannigan et al. 1998). For example, a decrease in the number of fires and a general decrease in the ignition frequency in the Canadian boreal forest (Bergeron and Archambault 1993) have been associated with increased precipitation since the end of the Little Ice Age (Archambault 
and Bergeron 1992). A decrease in fire frequency over the last two and a half centuries reported in British Columbia (Johnson et al. 1990) and in the southern Canadian Rockies (Johnson and Larsen 1991) may also have a climatic explanation. Other studies (Stocks et al. 1998; Amiro et al. 2001) predict increased fire hazards for the boreal regions of Canada and Russia as a result of increased global temperatures.

At present, without retrospective studies of fire-related weather in the Komi Republic, it is difficult to discuss the role of changing climate in the decreasing statistical fit between fires and tree-ring data. On a millennial scale, pollen-based reconstruction has suggested a decrease in the mean temperature of the warmest month for northeast Europe since 6000 BC. (Davis et al. 2003). However, dendrochronological reconstructions for the northern part of the Komi Republic show an unprecedented increase in the mean summer temperatures since AD 914 (Briffa et al. 1995). In line with this discrepancy is that a comparison of mean June temperatures for Siberia and the whole Northern Hemisphere indicates that a strong region-specific variation in climate may exist in this part of the boreal zone (Naurzbaev et al. 2002). Our own experience with pointer years in pine chronologies has demonstrated that annual climate variation in the Komi Republic was clearly different from that elsewhere, for example, the Fennoscandian region. It is likely that the answer to the question about trends in fire-related weather is dependent on the temporal and spatial scales under consideration. Also important to realize is that reconstructed indexes tend to underrepresent the actual weather variability (e.g., Grudd et al. 2002) that is controlling conditions for fire initiation and spread. Another difficulty arises from the fact that it is the temperature indexes and not, for example, aridity (temperature plus precipitation) reconstructions that are commonly available (e.g., see Naurzbaev et al. 2002; Grudd et al. 2002). A century-long instrumental data set for summer aridity, calculated as a function of average monthly temperature and the sum of precipitation for the summer months, shows a clearly increasing trend in the Komi Republic (I. Drobyshev, unpublished data). This may serve as an indication that, in Komi, changes in the climate have led to higher fire activity, at least during the 20th century.

\section{Conclusion}

Overall, long, seasonally resolved tree-ring fire histories coupled with tree-ring chronologies appear to be a promising tool for the analysis of interactions between climate, humans, and disturbance regime. The proposed ranking of the sites with respect to the strength of the climate-fire link may help researchers to understand reconstructed fire histories where the natural pattern dominates. Our results indicate the need for larger data sets, collected at various spatial scales, to enable further evaluation of this method's potential. A second possibility is to search for other proxies of fire-related weather (e.g., tree-ring density) that may be useful for this type of analysis.

\section{Acknowledgements}

Financial support for Igor Drobyshev was provided by the Department of Plant Ecology and Systematics at Lund Uni- versity and by the Stiftelsen Oscar och Lili Lamms through a Ph.D. fellowship. The authors thank Peter Brown and one anonymous reviewer for their stimulating comments on an earlier version of the manuscript and Louise Hathaway (Lund University) for linguistic help.

\section{References}

Amiro, B.D., Stocks, B.J., Alexander, M.E., Flannigan, M.D., and Wotton, B.M. 2001. Fire, climate change, carbon and fuel management in the Canadian boreal forest. Int. J. Wildl. Fire, 10: 405-413.

Aniol, R. 1983. Tree-ring analysis using CATRAS. Dendrochronologia, 1: 45-53.

Anufriev, V. (Editor). 2000. Land of virgin forests. Pechoro-Ilychsky Biosphere Reserve 2000. Edited by V. Anufriev. Syktyvkar, Russia. [In Russian.]

Archambault, S., and Bergeron, Y. 1992. An 802-year tree-ring chronology from the Quebec boreal forest. Can. J. For. Res. 22: 674-682.

Belitser, V.N. 1958. Ethnographical studies of Komi nations: XIXth - beginning of XXth century. Nauka Publishing House, Moscow.

Bergeron, Y., and Archambault, S. 1993. Decreasing frequency of forest fires in the southern boreal zone of Quebec and its relation to global warming since the end of the "Little Ice Age". Holocene, 3: 255-259.

Bergeron, Y., and Flannigan, M.D. 1995. Predicting the effects of climate change on fire frequency in the southeastern Canadian boreal forest. Water Air Soil Pollut. 82: 437-444.

Briffa, K.R., Jones, P.D., Schweingruber, F.H., Shiyatov, S.G., and Cook, E.R. 1995. Unusual 20th-century summer warmth in a 1,000-year temperature record from Siberia. Nature (Lond.), 376: $156-159$.

Davis, B.A.S., Brewer, S., Stevenson, A.C., and Guiot, J. 2003. The temperature of Europe during the Holocene reconstructed from pollen data. Quaternary Sci. Rev. 22: 1701-1716.

Dedeev, V. 1997. Geological structure. In Republic of Komi. Vol. I. Edited by P.M. Stolpovski. Komi Publishing House, Syktyvkar, Russia. pp. 18-20. [In Russian.]

Drobyshev, I., Niklasson, M., and Angelstam, P. 2004. Contrasting tree-ring data with fire record in a pine-dominated landscape in the Komi republic (Eastern European Russia): recovering a common climate signal. Silva Fenn. 38: 43-53.

Efron, B., and Tibshirani, R.J. 1994. An introduction to the bootstrap. Chapman \& Hall, New York.

Flannigan, M.D., Bergeron, Y., Engelmark, O., and Wotton, B.M. 1998. Future wildfire in circumboreal forests in relation to global warming. J. Veg. Science, 9: 469-476.

Fritts, H.C. 1976. Tree rings and climate. Academic Press, London.

Granström, A. 1993. Spatial and temporal variation in lightning ignitions in Sweden. J. Veg. Sci. 4: 737-744.

Grissino-Mayer, H., Holms, R., and Fritts, H. 1997. International tree-ring data bank program library manual. Laboratory of Tree-Ring Research, University of Arizona, Tucson, Ariz.

Grudd, H., Briffa, K.R., Karlen, W., Bartholin, T.S., Jones, P.D., and Kromer, B. 2002. A 7400-year tree-ring chronology in northern Swedish Lapland: natural climatic variability expressed on annual to millennial timescales. Holocene, 12: 657-665.

Heyerdahl, E.K., Brubaker, L.B., and Agee, J.K. 2001. Spatial controls of historical fire regimes: a multiscale example from the interior West, USA. Ecology, 82: 660-678. 
Johnson, E.A. 1992. Fire and vegetation dynamics: studies from the North American boreal forest. Cambridge Studies in Ecology. Cambridge University Press, Cambridge.

Johnson, E.A., Fryer, G.I., and Heathcott, M.J. 1990. The influence of man and climate on frequency of fire in the interior Wet Belt Forest, British Columbia. J. Ecol. 78: 403-412.

Johnson, E.A., and Larsen, C.P.S. 1991. Climatically induced change in fire frequency in the Southern Canadian Rockies. Ecology, 72: 194-201.

Kalela-Brundin, M. 1999. Climatic information from tree-rings of Pinus sylvestris L., and a reconstruction of summer temperatures back to AD 1500 in Femundsmarka, eastern Norway, using partial least squares regression (PLS) analysis. Holocene, 9: 59-77.

Komi ASSR administrative map. 1981. GUGK, Moscow. [In Russian.]

Konakov, N.D. 2004. Agriculture. In Traditional culture of European North-East of Russia [online]. Available from http://www.komi.com/Folk/komi/txt84.htm [accessed 24 February 2004]. [In Russian.]

Kozubov G.M., and Taskaev A.I. (Editors). 1999. Lesnoe khozjaistvo i lesnie resursi Respubliki Komi (Forestry and forest resources of Komi republic). DiK Publishing House, Moscow. [In Russian.]

Kutzbach, J.E., and Webb, T., III. 1993. Conceptual understanding of climate change. In Global climates since the last glacial maximum. Edited by H.E. Wright Jr., J.E. Kutzbach, T. Webb III, W.F. Ruddiman, F.A. Street-Perrott, and P.J. Bartlein. University of Minnesota Press, Minneapolis, Minn. pp. 5-11.

Larin, V. 1999. Forests, their exploitation and regeneration. In Republic of Komi. Vol. I. Edited by P.M. Stolpovski. Komi Publishing House, Syktyvkar, Russia. pp. 34-40. [In Russian.]

Lehtonen, H., Huttunen, P., and Zetterberg, P. 1996. Influence of man on forest fire frequency in North Karelia, Finland, as evidenced by fire scars on Scots pines. Ann. Bot. Fenn. 33: 257-263.

Nash, C.H., and Johnson, E.A. 1996. Synoptic climatology of lightning-caused forest fires in subalpine and boreal forests. Can. J. For. Res. 26: 1859-1874.

Naurzbaev, M.M., Vaganov, E.A., Sidorova, O.V., and Schweingruber, F.H. 2002. Summer temperatures in eastern Taimyr inferred from a 2427-year late-Holocene tree-ring chronology and earlier floating series. Holocene, 12: 727-736.

Niklasson, M., and Drakenberg, B. 2001. A 600-year tree-ring fire history from Norra Kvills National Park, southern Sweden: implications for conservation strategies in the hemiboreal zone. Biol. Conserv. 101: 63-71.
Niklasson, M., and Granström, A. 2000. Numbers and sizes of fires: long-term spatially explicit fire history in a Swedish boreal landscape. Ecology, 81: 1484-1499.

Pyne, S.J. 1996. Wild hearth: a prolegomenon to the cultural fire history of northern Eurasia. In Fire in ecosystems of boreal Eurasia. Edited by J.G. Goldammer and V.V. Furyaev. Kluwer Academic Publishers, Dordrecht. pp. 21-44.

Republic of Komi. 1997-2000. Vols. I, II, and III. Edited by P.M. Stolpovski. Komi Publishing House, Syktyvkar, Russia. [In Russian.]

Smirnov, A.P. 1952. Studies of ancient and middle-age history of nations in Middle Volga and Kama regions. Publ. 28. Moscow Institute of Archaeology, Moscow. [In Russian.]

Stokes, M.A., and Smiley, T.L. 1968. An introduction to tree-ring dating. University of Chicago Press, Chicago, Ill.

Stocks, B.J., Fosberg, M.A., Lynham, T.J., Mearns, L., Wotton, B.M., Yang, Q., Jin, J.Z., Lawrence, K., Hartley, G.R., Mason, J.A., and McKenney, D.W. 1998. Climate change and forest fire potential in Russian and Canadian boreal forests. Clim. Change, 38: $1-13$.

Swetnam, T.W. 1996. Fire and climate history in the Central Yenisey region, Siberia. In Fire in ecosystems of boreal Eurasia. Edited by J.G. Goldammer and V.V. Furyaev. Kluwer Academic Publishers, Dordrecht. pp. 90-104.

Veblen, T.T., Kitzberger, T., Villalba, R., and Donnegan, J. 1999. Fire history in northern Patagonia: the roles of humans and climatic variation. Ecol. Monogr. 69: 47-67.

Veblen, T.T., Kitzberger, T., and Donnegan, J. 2000. Climatic and human influences on fire regimes in ponderosa pine forests in the Colorado Front Range. Ecol. Appl. 10: 1178-1195.

Weber, M.G., and Stocks, B.J. 1998. Forest fires in the boreal forests of Canada. In Large forest fires. Edited by J. M. Moreno. Backhuys Publishers, Leiden, Netherlands. pp. 215-233.

Wigley, T.M.L, Briffa, K.R., and Jones, P.D. 1984. On the average value of correlated time series, with applications in dendroclimatology and hydrometeorology. J. Clim. Appl. Meteorol. 23: 201-213.

Zaboeva, I. 1997. Soils. In Republic of Komi. Vol. I. Edited by P.M. Stolpovski. Komi Publishing House, Syktyvkar, Russia. pp. 30-34. [In Russian.]

Zherebtsov, L.N. 1971. Farmers' housing in Komi republic. Komi Publishing House, Syktyvkar, Russia [In Russian.]

Zherebtsov, L.N. 1972. Distribution of Komi people in XVth-XIXth centuries. Komi Publishing House, Syktyvkar, Russia. [In Russian.] 